\title{
Effectiveness Extending Concept Through Language Activities (ECOLA) Method in Learning Editing Student Scientific Articles
}

\author{
Asep Supriyana ${ }^{1, a),{ }^{*}}$, Emzir $^{2, b)}$, Endry Boeriswati ${ }^{2, c)}$ \\ ${ }^{1}$ Program Studi Sastra Indonesia, Fakultas Bahasa dan Seni, Universitas Negeri Jakarta \\ ${ }^{2}$ Program Doktor Ilmu Pendidikan Bahasa Universitas Negeri Jakarta \\ aasep.supriyana@unj.ac.id, bemzir.unj@unj.ac.id, 'endry.boeriswati@unj.ac.id
}

\begin{abstract}
This study aims to determine the effectiveness of the ECOLA method on the ability to edit scientific articles of students. The method used in this research is the expriment method. This method is used to examine the possibility of a causal relationship, by exposing one or more experimental groups and one or more experimental conditions. The design used in this study is the pretest posttest control group design. This research was conducted at the Indonesian Literature Study Program, Faculty of Language and Art, Jakarta State University. In this study, the independent variable is the ECOLA learning method and the dependent variable is the ability to edit scientific articles. Based on the research results it is known that there is an effective ECOLA method used to improve the ability to edit scientific articles of students
\end{abstract}

Keywords: ECOLA methods, editing skills, scientific articles

\begin{abstract}
Abstrak
Penelitian ini bertujuan untuk mengetahui efektivitas metode ECOLA terhadap kemampuan menyunting artikel ilmiah mahasiswa. Metode yang digunakan dalam penelitian ini adalah metode exprimen. Metode ini digunakan untuk meneliti kemungkinan hubungan sebab akibat, dengan cara mengekspos satu atau lebih kelompok eksperimental dan satu atau lebih kondisi ekperimen. Desain yang digunakan dalam penelitian ini adalah pretest posttest control group design. Penelitian ini dilaksanakan di Program Studi Sastra Indonesia, Fakultas Bahasa dan Seni, Universitas Negeri Jakarta. Dalam penelitian ini, variabel bebas berupa metode pembelajaran ECOLA dan variabel terikatnya adalah kemampuan menyunting artikel ilmiah. Berdasarkan hasil penelitian diketahui terdapat metode ECOLA efektif digunakanuntukl meningkatkan kemampuan menyunting artikel ilmiah mahasiswa.
\end{abstract}

Kata kunci: metode ECOLA, kemampuan menyunting, artikel ilmiah 


\section{PENDAHULUAN}

Profesi penyunting di media penerbitan menjadi bagian yang penting dalam proses penebitan teks. Teks yang diterbitkan dapat berupa buku, teks berita, artikel ilmiah, dan sebagainya. Seiring dengan perkembangan teknologi, teks-teks tersebut tidak hanya diterbitkan dalam bentuk cetak, tetapi juga dalam bentuk digital. Walaupun begitu, apapun mendianya, penyuntingan teks menjadi bagian yang penting dalam penerbitan, karena penyuntingan sangat menentukan sebuah teks disukai dan dibaca masyarakat.

Di Program Studi Sastra Indonesia UNJ (PSSI UNJ) setiap mahasiswa diberikan mata kuliah Dasar-Dasar Penyuntingan dengan tujuan membekali lulusan PSSI dengan komptensi di bidang penyuntingan teks. Mata kuliah ini dibuka berdasarkan hasil studi pelacakan lulusan yang dilakukan sedikitnya setiap lima tahun sekali. Informasi tentang kesenjangan penyunting bahasa dengan kompetensi kebahasaan selalu menjadi informasi dari hasil studi tersebut. Untuk itu, PSSI UNJ perlu menyiapkan lulusan yang memiliki komptensi di bidang penyuntingan bahasa dengan membuka mata kuliah Dasar-Dasar Penyuntingan. Melalui mata kuliah tersebut, mahasiswa diajarkan DasarDasar Penyuntingan dan bagaimana menyunting berbagai teks.

Di antara jenis teks yang dijadikan materi penyuntingan di atas adalah teks artikel ilmiah. Artikel ilmiah ini sering dijadikan alat ukur bagi ketercapaian perkuliahan beberapa mata kuliah. Dosen sering menugaskan mahasiswa untuk membuat artikel ilmiah berdasarkan penelitian dan pengkajian ilmiah yang dilakukan mahasiswa. Bahkan di akhir masa studi, seorang mahasiswa diwajibkan untuk membuat tugas akhir dalam bentuk laporan penelitian (skripsi, tesis, atau disertasi). Bedasarkan laporan penelitian ini, mahasiswa harus membuat artikel ilmiah dan mempublikasikannya pada jurnal ilmiah dengan tingkat akreditasi tertentu.

Berdasarkan pengamatan hasil pembelajaran Dasar-Dasar Penyuntingan di PSSI, masih muncul kesalahan-kesalahan kebahasaan yang luput dari penyuntingan mahasiswa, seperti kesalahan ejaan dan tanda baca, pilihan kata, kalimat efektif, dan pengembangan paragraf. Jika diperhatikan dari kasus-kasus penyuntingan aspek kebahasaan di atas, ada beberapa penyebab mengapa kesalahan-kesalahan tersebut luput dari penyuntingan mahasiswa.

Berdasarkan masukan mahasiswa yang dikemukakan pada bagian saran dalam laporan kegiatan magang di penerbitan, salah satu penyebab masih ada aspek-aspek kebahasaan yang luput dari penyutingan adalah monotonnya metode yang digunakan dalam menyunting teks. Oleh karena itu, peneliti melakukan uji coba penggunaan metode extending concept through language activities (ECOLA) dalam pembelajaran menyunting artikel ilmiah. Adapun masalah yang dirumuskan adalah bagaimana efektivitas metode extending concept through language activities (ECOLA) dalam pembelajaran menyunting artikel ilmiah mahasiswa?

Menyunting teks merupakan kegiatan memperbaiki teks dalam dalam bentuk penambahan, pengurangan, atau penyesuaian aspek-aspek yang berkaitan dengan teks agar siap dipublikasikan. Teks yang siap dipublikasikan seharusnya tidak lagi memiliki masalah terkait dengan bahasa, materi, format, dan gaya selingkungnya.

Dalam menyntuing teks, sebenarnya bukan hanya masalah bahasa yang menjadi fokus perbaikan teks, melainkan ada aspek lain yang juga harus diperhatikan seorang penyunting. Burrough-Boenisch (2012: 144), mengemukakan, "It should by now be clear that a text in any language can be edited, and that correcting errors of language 
is only a part ofediting." Teks dalam bahasa apa pun dapat disunting, dan memperbaiki kesalahan bahasa hanyalah sebagian dari penyuntingan.

Biasanya teks disunting oleh beberapa orang penyunting, dan masing-masing penyunting memiliki tugas yang berbeda-beda. Jika diamati, ada tiga kegiatan dalam neyunting teks. Mennurut Burrough-Boenisch \& Matarese (2012: 177-178), berdasarkan jenis pekerjaannya penyunting dapat dikelompokkan ke dalam tiga tingkatan, yaitu copy editing (penyuntigan salinan), language editing (penyuntingan bahasa) dan substantive editing (penyuntingan substansi).

Secara mendasar, Trimansyah (2010: 7), mengungkapan lima kegiatan dasar penyuntingan yang hal spesifik, yaitu;

1) Pemakluman; membaca awal (first reading) kemudian memaklumkan kebenaran teks sehingga tetap sesuai dengan aslinya;

2) Perbaikan; memperbaiki teks sesuai dengan gaya selingkung, PUEBI, atau Kamus Besar Bahasa Indonesia sehingga menjadi baik dan benar;

3) Pengubahan; mengubah teks pada tingkat struktur kalimat, struktur paragraf, ataupun struktur outline sehingga lebih mudahdipahami dan runtut;

4) Pengurangan; mengurangi bagian-bagian teks yang dianggap tidak perlu atau tidak relevan dengan teks, termasuk juga dalam hal penyesuaian banyaknya halaman teks.

5) Penambahan; menambah bagian-bagian teks yang dianggap perlu atau sangat relevan, termasuk juga dalam hal penyesuaian banyaknya halaman teks.

Dipilihnya metode ECOLA sebagai salah satu variabel dalam penelitian ini, karena metode ECOLA merupakan salah satu metode metode membaca. Metode membaca merupakan sangat erat kaitannya dengan kegiatan menyunting, karena kegiatan utama dalam menyunting teks adalah membaca. Kualitas suntingan sangat tergantung pada kemampuan membaca pemahaman penyunting.

Metode ECOLA dianggap dapat meningkatkan kemampuan membaca. Metode ini memadukan empat keterampilan berbahasa, yaitu mendengarkan, berbicara, membaca, dan menulis (Susanto, 2014; 152). Metode ECOLA juga memiliki prosedur yang dapat meningkatkan kemampuan membaca, yaitu 1) menentukan tujuan komunikatif; 2) membaca dalam hati; 3) menulis pemahaman; 4) berdiskusi mengenai materi bacaan; dan 5) menulis (Susanto, 2014: 152).

Telah banyak dilakukan penelitian terkait dengan efektivitas metode ECOLA dalam meningkatkan kemampauan membaca pemahaman. Salah satunya dapat dilihat pada penelitian yang dilakukan Tumpu (2018: 29) tentang efektivitas metode ECOLA dalam meningkatkan keterampilan membaca pemahaman teks siswa SMA. Hasilnya menunjukkan bahwa metode ECOLA efektif dalam meningkatkan keterampilan membaca pemahaman teks siswa SMA.

Metode ini memiliki beberapa kelebihan. Evanirmala (2018: 5) mencatat lima kelebihan dari metode ECOLA, yaitu: 1) peserta didik berkerja secara individu untuk melatih dan meningkatkan kemampuan membaca; 2) melatih peserta didik untuk bekerja sama dalam suatu kelompok diskusi; 3) memungkinkan peserta didik untuk saling bertukar pikiran dari hasil kerja individu yang kemudian didiskusikan dalam kelompok; 4) peserta didik akan memperoleh pengalaman belajar baik melalui belajar mandiri dengan membaca dan menulis; dan 5) peserta didik memperoleh pengalaman belajar melalui tukar pendapat dan gagasan.

Metode ECOLA digunakan dalam pembelajaran membaca dengan mengintegrasikan empat keterampilan dasar berbahasa untuk mencapai pemahaman bacaan. Melalui metode ini.peserta didik dirangsang untuk memaksimalkan kemampuan 
alamiahnya dalam memahami suatu bacaan. Smith-Burke dalam Susanto (2014: 152) mengemukakan bahwa bahwa ECOLA merupakan metode yang memfokuskan suatu kegiatan untuk membangun kemampuan secara alamiah membaca dan proses monitoring terhadap pemahaman terhadap suatu bacaan.

Tierney, dkk. (1990) mengemukakan bahwa metode ECOLA memfokuskan kegiatan untuk menggunakan kemampuan alamiah peserta didik dalam membaca dan monitoring pemahaman mereka terhadap teks yang dibanya. Oleh karena itu, kerangka pembelajaran ECOLA terletak pada pengalaman pengalaman belajar peserta didik, yakni membaca dengan tujuan tertentu, tanggapan tertulis, diskusi, dan selfmonitoring.

Keterampilan membaca merupakan salah satu keterampilan berbahasa yang memiliki kaitan yang erat dengan keterampilan berbahasa lainnya. Akan tetapi, dalam proses pembelajaran, kadang-kadang pendidikan mengabaikan keterakiatan antara keterampilan membaca dengan keterampilan lainnya. Melalui metode ECOLA ini, pembelajaran membaca dapat dilakukan dengan melibatkan kemampuan berbahasa lainnya, sehingga hasil pembelajaran membacaa dapat dioptimalkan.

\section{METODE PENELITIAN}

Metode yang digunakan dalam penelitian ini adalah metode exprimen. Metode ini digunakan untuk meneliti kemungkinan hubungan sebab akibat, dengan cara mengekspos satu atau lebih kelompok eksperimental dan satu atau lebih kondisi ekperimen. Desain yang digunakan dalam penelitian ini adalah pretest posttest control group design. Sampel dalam penelitian ini adalah mahasiswa Program Studi Sastra Indonesia yang terdaptar pada semester ganjil 2018/2019 dan yang sedang mengambil mata kuliuah Dasar-Dasar Penyuntingan. Untuk memperoleh data penelitian ini digunakan instrumen. Instrumen yang digunakan, yaitu tes kemampuan menyunting artikel ilmiah. Pembelajaran dilaksanakan selama enam kali pertemuan. Pertemuan diberikan pertama pretest dan pertemuan keenam diberikan posttest yang dilaksanakan dikelas kontrol dan eksperimen. Pertemuan ke-2 sampai dengan ke-5 adalah perlakukan.

\section{HASIL DAN PEMBAHASAN}

Beradasarkan hasil analisis statistik, $\mathrm{F}_{\text {hitung }} 26,053>\mathrm{F}_{\text {tabel }} 4,17$, artinya terdapat pengaruh yang sangat signifikan antara metode ECOLA terhadap kemampuan menyunting artikel ilmiah berbahasa Indonesia mahasiswa. Hasil analisis statistik tersebut relevan dengan hasil tes awal dan tes akhir yang dilakukan di kelas ekperimen.

Jika dibandingkan dengan nilai rata-rata tes awal pada kelompok mahasiswa yang diberi perlakuan dengan metode ECOLA, nilai rata-rata tes akhir kelompok ini menunjukan peningkatkan yang signifikan. Nilai rata-rata tes awal kelompok ini sebesar 61,2 , sedangkan nilai rata-rata tes akhir meningkat 71,8. Peningkatan ini disebabkan oleh efektvitas dari metode ECOLA yang digunakan sebagai perlakukan.

Tes awal diberikan untuk mengetahui kemampuan awal menyunting artikel ilmiah yang dimiliki mahasiswa sebelum diberi perlakuan dengan metode ECOLA. Di akhir pembelajaran, mahasiswa diberi tes untuk mengetahui hasil belajar akhir belajar. Hasil akhir ini menjadi indikator adanya pengaruh dari metode yang digunakan.

Metode ECOLA merupakan metode membaca yang memadukan empat keterampilan berbahasa. Dalam penelitian ini, metode ECOLA menujukkan pengaruh yang positif terhadap kemampuan menyunting. Berdasarkan hal tersebut, pembelajaran 
bahasa dengan memfokuskan kepada salah satu kemampuan, sebaiknya dilakukan secara holistik dengan memadukan keempat kemampuan bahasa, agar hasilnya dapat maksimal.

Zuchdi (2012) mengemukakan bahwa metode ECOLA dapat meningkatkan kemampuan pemahaman bacaan. Jika pemahaman bacaan yang baik ini digunakan untuk menyunting artikel ilmiah, sangat memungkinkan dihasilkan hasil suntingan yang baik, sebagaimana metode ini digunakan untuk meningkatkan sebuah kemampuan sebagai hasil belajar. Melalui metode ECOLA, mahasiswa dapat memiliki pemahaman mahasiswa yang diperlukan untuk mrenyunting artikel ilmiah, karena metode ECOLA memuat proses monitoring terhadap hasil interpretasi.

Selain itu, metode ECOLA mendorong mahasiswa untuk mendiskusikan metode yang efektif untuk memperoleh pemahaman yang baik. Proses diskusi dalam metode ECOLA mampu membangun kemampuan mahasiswa untuk bekerja sama dalam tim. Dengan penerapan ECOLA suasana dalam proses pembelajaran menjadi lebih dinamis. Siswa terlatih untuk memberikan respon dan argumentasi mereka menjadi lebih baik.

Dalam pembelajaran, metode ECOLA diterapkan dengan memaksimalkan keterpaduan empat keterampilan berbahasa, yaitu menyimak, membaca, menulis, dan berbicara. Melalui keempat kegiatan ini, mahasiswa dapat memiliki pemahaman membaca yang bertingkat. Ruddel dalam Nurbaya dkk. (2018) membagi pemahaman menjadi tiga aspek tingkat pemahaman, yaitu 1) pemahaman faktual. 2) pemahaman interpretatif, dan 3) pemahaman aplikatif.

Tingkat pemahaman faktual berkaitan dengan kemampuan mahasiswa dalam memahami informasi yang tersirat dalam bacaan. Untuk mendapatkan pemahaman faktual dapat dilakukann dengan kegiatan membaca dalam hati. Melaui kegiatan ini, mahasiswa dapat menemukan aspek-aspek penyuntingan dalam artikel ilmiah yang diusnting. Semua aspek yang salah dan sudah benar yang terdapat dalam artikel ilmiah merupakan aspek-aspek yang bersifat faktual. Kegiatan membaca dalam hati merupakan salah satu tahapan dari metode ECOLA.

Tahapan lain dari metode ECOLA adalah menuliskan pemahaman pembaca tentang teks yang dibacanya. Dalam menyunting artikel ilmiah, mahasiswa perlu memahami keseluruhan teks tersebut. Pemahaman yang dimaksud di sini tentu tidak hanya mengetahui aspek-aspek faktual yang terdapat dalam artikel ilmiah, tetapi menyangkut keseluruhan artikeli ilmiah, termasuk insformasi-informasi yang tersurat. Pemahaman seperti ini oleh Ruddel termasuk tingkat pemhaman kedua, yaitu pemahaman interpretatif. Tingkat pemahaman ini berkaitan dengan kemampuan mahasiswa dalam memahami informasi yang tersirat dalam bacaan.

Tahap awal metode ECOLA adalah mahasiswa diminta untuk menentukan tujuan komunikatif dari kegiatan membaca artikel ilmiah. Kegiatan ini merupakan upaya awal bagi mahasiswa dalam memperoleh pemahaman interpretatif dari artikel ilmiah yang dibacanya. Tujuan yang telah ditulis mahasiswa, kemudian di buktikan secara faktual dari teks melalui kegiatan membaca. Setelah memperoleh informasiinformasi faktual dari teks tersebut, mahasiswa menuangkan pemahaman dalam bentuk tulisan.

Tingkat ketiga adalah pemahaman aplikatif, yaitu pemahaman yang berkaitan dengan kemampuan siswa dalam menerapkan isi bacaan untuk menemukan apa yang dikatakan dan dimaksudkan oleh pengarang. Dalam penelitian itu, kegiatan menyunting merupakan perwujudan dari pemahaman aplikatif dari kedua tingkat pemahaman sebelumnya, yaitu pemahaman faktual dan pemahaman interpretatif. 
Salah satu prinsip dari metode ECOLA adalah memadukan empat aspek kebahasaan. Keempat aspek ini dimaksimalkan dalam proses pembelajaran mrmbaca. Kemampuan membaca mahasiswa merupakan kemampuan utama yang digunakan dalam menyunting teks. Pengintegrasian empat kemampuan berbahasa efektik digunkan untuk meningkatkan kemampuan menyunting artikel ilmiah mahasiswa. Jika dibandingkan dengan nilai tes awal, metode ini memang dapat meningkatkan kemampuan menyunting artikel ilmiah mahasiswa . Akan tetapi, peningkatkannya tidak seefektif pada proses pembelajaran yang memaksimalkan aktivitas berpikir mahasiswa, seperti pada metode DRTA.

\section{KESIMPULAN}

Berdasarkan hasil uji statistik, dapat disimpulkan bahwa semua hipotesis yang dikemukakan di depan menujukkan Ho ditolak. Hal ini berarti terdapat pengaruh metode ECOLA terhadap kemampuan menyunting arrtikel ilmiah mahasiswa. Metode ECOLA yang memadukan empat aspek kebahasaan. Keempat aspek ini dimaksimalkan dalam proses pembelajaran mrmbaca. Kemampuan membaca mahasiswa merupakan kemampuan utama yang digunakan dalam menyunting teks.

\section{REFERENSI}

Abidin, Y. (2012). Pembelajaran Membaca Berbasis Pendidikan Karakter. Bandung: Refika Aditama.

Burrough-Boenisch, J. (2012). "Defining and Describing Editing." In Supporting Research Writing: Roles and Challenges in Multilingual Settings (pp. 141155). https://doi.org/10.1016/B978-1-84334-666-1.50009-6

Burrough-Boenisch, J., \& Matarese, V. (2012). "The Authors" Editor: Working with Authors to Make Drafts Fit for Purpose". Supporting Research Writing: Roles and Challenges in Multilingual Settings. Woodhead Publishing Limited. https://doi.org/10.1016/B978-1-84334-666-1.50011-4

Evanirmala, S. (2018). "Peningkatan kemampuan mengidentifikasi unsur intrinsik hikayat dengan teknik ecola siswa SMA Sinar Kasih Sintang." Universitas Tanjungpura.

Nurbaya, S., Rahman, F., Rustono, \& Subyantoro. (2018). "Pengaruh Skemata Terhadap Kompetensi Membaca Pemahaman Berbasis Taksonomi Ruddell". Litera, 17(1), 117-140. https://doi.org/10.1177/026553228500200202

Susanto, H. (2014). "Metode Extending Concepts Throught Language Activities (ECOLA) dalam Pembelajaran Membaca Pamahaman Biografi”. Lokabasa, $5(2), 150-155$.

Trimansyah, B. (2017). 200+ Solusi Editing Naskah dan Penerbitan. (Y. N. I. Sari, Ed.) (Pertama). Jakarta: Bumi Aksara. 
Tumpu, A. B. (2018). "Efektivitas Metode Extending Concept Through Language Activities (ECOLA) dalam Meningkatkan Keterampilan Membaca Pemahaman Teks Siswa Kelas X SMA Negeri 1 Enrekang.” Algazali Journal, 1(1). 